\title{
Measure phrases as modifiers of adjectives
}

\section{Roger Schwarzschild}

\section{OpenEdition}

Journals

Édition électronique

URL : http://journals.openedition.org/rlv/1401

DOI : $10.4000 /$ rlv. 1401

ISSN : 1958-9239

\section{Éditeur}

Presses universitaires de Vincennes

\section{Édition imprimée}

Date de publication : 1 décembre 2005

Pagination : 207-228

ISBN : 2-84292-176-3

ISSN : 0986-6124

\section{Référence électronique}

Roger Schwarzschild, "Measure phrases as modifiers of adjectives », Recherches linguistiques de Vincennes [En ligne], 34 | 2005, mis en ligne le 22 décembre 2006, consulté le 01 mai 2019. URL: http://journals.openedition.org/rlv/1401; DOI : 10.4000/rlv.1401 


\title{
Roger SCHWARZSCHILD \\ Rutgers University
}

\section{MEASURE PHRASES AS MODIFIERS OF ADJECTIVES ${ }^{1}$}

\begin{abstract}
In some languages, measure phrases can appear with non-compared adjectives: 5 feet tall. I address three questions about this construction: (a) Is the measure phrase an argument of the adjective or an adjunct? (b) What are we to make of the markedness of this construction *142lbs heavy? (c) Why is it that the markedness disappears once the adjective is put in the comparative (2 inches taller alongside 2 lbs heavier)?

I claim that because degree arguments are 'functional', the measure phrase has to be an adjunct and not a syntactic argument of the adjective. Like event modifiers in extended NPs and in VPs, the measure phrase predicates of a degree argument of the adjective. But given the kind of meaning a measure phrase must have to do its job in comparatives and elsewhere, it is not of the right type to directly predicate of a degree argument. I propose a lexically governed type-shift which applies to some adjectives allowing them to combine with a measure phrase.
\end{abstract}

\section{KEYWORDS}

Adjective, measure phrase, degree, functional category, lexical, adjunct, argument, antonymy. 


\section{Introduction}

There is a widely accepted account of expressions like five feet tall according to which the adjective tall denotes a relation between individuals and degrees of height and the measure phrase, five feet, serves as an argument of the adjective, saturating the degree-place in the relation ${ }^{2}$. This account has much to recommend it. A measure phrase is just a special kind of noun phrase and noun phrases are the canonical category for arguments of predicates. The combination is interpreted via function-application, a simple and familiar operation. And the degree argument for the adjective is independently justified by the role it plays in the analysis of the superlative, the comparative, too and enough.

Having said what I think is right about the argument account of preadjectival measure phrases ${ }^{3}$, let me say what's wrong with it. The area to the left of the adjective is normally associated with modifiers of the adjective (e.g. extremely tall) whereas internal arguments of adjectives usually appear to the right (sick of working). Nouns and verbs tend to follow the same pattern, at least with respect to arguments. If the measure phrase is indeed an argument of the adjective, we need an explanation for why we have five feet tall and not *tall (of) five feet. We also need an explanation for why the main stress is on tall in five feet táll, when the general rule in English is that in neutral contexts a predicate is less stressed than its argument ${ }^{4}$.

On the view in question, if John is five feet tall, then five feet names John's height. That seems to imply that John's height itself refers to a (degree of) height. But then why is it impossible to say *John's height tall? Likewise, why can we say John is 10 years old, but not *Mary is John's age old?

I'd like to suggest an answer to this last question, one that will lead to a deeper problem with the argument account of five feet tall. In many respects the degree-argument position of a gradable adjective behaves like nonthematic arguments such as event-arguments and temporal and modal arguments. The degree argument can be bound by function words such as too in too tall or the comparative morpheme er in taller. This type of binding is consistent across all gradable adjectives. Unlike with thematic arguments, it is not subject to the vicissitudes of subcategorization. The tenses similarly are expressed by functional morphemes and bound by when and no verb's temporal argument can resist their binding. Modals are likewise functional expressions that are often taken to freely bind world variables. Adjuncts such as surprisingly, extremely and perhaps very can be used to predicate of the degree argument (Klein, 1998), just as adjuncts predicate of event arguments and temporal arguments. Non-thematic arguments are so-called because they cannot be saturated with noun phrases. The impossibility of $* 10: 00$ kill my $d o g$ is not to be held against the view that kill has a temporal argument, nor 
should *Jack killed a dog Fido's murder be held against those who claim that the verb kill has an event place. 10:00 and Fido's murder are the wrong kinds of expressions to fill a temporal or an event argument slot. And similarly, the ungrammaticality of *my father's height tall is expected because although tall has a degree argument, that argument is non-thematic. The noun phrase my father's height is the wrong kind of thing to occupy the degree-argument slot. In the taxonomy of Higginbotham (1985), degree arguments, like eventarguments are q-identified or q-bound, but are not discharged by q-marking. This means that since measure phrases are just a special kind of noun phrase, the idea that they can occupy the degree argument slot of a gradable adjective in fact runs counter to what one would expect.

There is another consideration that is independent of the previous ones and which presents a problem for all existing accounts of measure phrases in adjective phrases, not just the measure-phrase-as-argument account. The ability of an adjective to combine directly with a measure phrase turns out to be somewhat of a lexical idiosyncrasy. Unlike tall, there are many adjectives that have 'syntactically visible' degree arguments but that do not combine with appropriate measure phrases. The example in (1) shows a comparative binding the degree argument of expensive in conjunction with an appropriate measure phrase, five dollars. Example (2)shows that the measure phrase cannot directly combine with the adjective.

(1) five dollars more expensive

(2) *five dollars expensive

There are languages in which all adjectives are like expensive in resisting direct combination with appropriate measure phrases. The virtue of the function-argument analysis is its simplicity. Since this type of operation occurs elsewhere in the grammar, nothing special needs to be said beyond the interpretation of the adjective as a function and the measure phrase as an argument. But if nothing special is said about five feet tall then nothing can be unsaid about *five dollars expensive.

In the following pages, I plan to give an account in which preadjectival measure phrases are modifiers. They do their work as predicates of non-thematic degree arguments just as Davidsonian adverbs and some prenominal adjectives do their work as event-predicates (Larson, 1998). As we will discover, the semantics of the measure phrase is such as to require an adjustment in the meaning of the adjective in order to allow this type of modification to go through. This adjustment will be stated as a lexical rule that applies to tall but not to expensive. 


\section{The distribution of measure phrases in adjectival phrases}

As just noted, it is quite often the case that a measure phrase cannot be directly combined with an appropriate adjective (*five dollars expensive), even though it can be used in a comparative (five dollars more expensive). All of the examples in (3)-(5) are ungrammatical, and in every case they would be made grammatical if the adjective were put in the comparative:
a. *6 lbs heavy/light
j. *2 percentage points likely
b. $* 30^{\circ} \mathrm{hot} / \mathrm{cold} / \mathrm{warm}$
k. *2 degrees acute
c. $* 80 \mathrm{mph}$ fast/slow
1. *it takes 2 days long
d. *\$5 cheap/expensive
m.*200 pounds fat/thin
e. *2 inches big/small
n. *The winds are $25 \mathrm{mph}$ strong.
f. *3 shades dark/light
o. *30 miles close/far/near
g. $* 50$ decibels loud/soft
p. $* 600$ watts powerful ${ }^{5}$
h. $* \$ 10^{6} \mathrm{rich} /$ poor
q. $* 20$ points popular
i. *20 IQ points intelligent/stupid
r. *20pts well/bad on the exam

(4) Examples from Murphy (1997)
a. *40 square meters large
b. *8 scovils hot (measurement of chili-hotness)
c. *3 chroma saturated (measurement of gray tone in a color)
a. $* 2$ inches narrow/short/shallow/low/thin
b. *2 years young/short/new

The adjectives in(5) represent a special case because they all have antonyms that do combine directly with measure phrases. A lot has been said concerning this asymmetry and we will draw on those insights in our discussion below.

The data in(3)-(5) shows that direct combination with a measure phrase is lexically conditioned. Further evidence for this conclusion comes from a comparison between languages, where we find differences in the set of adjectives that support this construction. In (6)-(9), I've listed grammatical examples whose English counterparts are ungrammatical ${ }^{6}$ :

pesante [quasi due tonnellate]

heavy almost 2 tons

'weighs almost two tons'

(Italian. Zamparelli, 2000 : 284)

is 2 boeken rijk

is books rich

'owns two books'

(Dutch. Corver, 1990: 224)

(8) Het dorp is twee kilometer ver the village is $2 \mathrm{~km}$ far 'the village is two kilometers away'

(Dutch. Seuren, 1978) 
a. $35^{\circ}$ heiss, ' $35^{\circ}$ hot'

(German)

b. $-10^{\circ}$ kalt ' $-10^{\circ}$ cold'

c. 100 Tonnen schwer ' 100 tons heavy'

d. 130 Meter gross ' 130 meters big'?

e. 60 Stundenkilometer schnell ' 60 kilometers-per-hour fast'

I have found that generally, if an adjective in English directly combines with a measure phrase, its German translation does too but not viceversa. Two exceptions to this rule are late and early. *zwei Minuten spät 'two minutes late' and *zwei Minuten früh 'two minutes early' are both ungrammatical.

French adjectives, when they do combine with a measure phrase, prefer it on the right:

(10) haut de $1,27 \mathrm{~m}$

' $1.27 \mathrm{~m}$ high'

(French)

(11) épais de $20 \mathrm{~cm}$

'20 cm thick'

While tall is the stock example of an adjective that combines directly with a measure phrase, its closest counterpart in French does not combine with a measure phrase:

$$
\text { *grand de } 1,27 \mathrm{~m} \quad \text { ' } 1.27 \mathrm{~m} \text { tall' }
$$

Of course, when grand 'tall' is used in the comparative or in a deadjectival verb, the measure phrase is fine:

(13) est plus grand que Marie de 2 centimètres

(French)

is more tall than Marie by 2 centimeters

'is $2 \mathrm{~cm}$ taller than Marie'

(14) a grandi de $2 \mathrm{~cm}$ 'grew $2 \mathrm{~cm}$ '

(French)

The adjective profond 'deep' differs in the same way from its English counterpart, while the adjective riche goes the other way. It does combine with a measure phrase while its English counterpart does not:

riche de deux millions

(French)

'rich to $\$ 2$ million' ('is worth $\$ 2$ million')

Some languages never allow for measure phrases directly combining with an adjective, even though they do allow measure phrases in comparatives. These languages include Japanese (Snyder et al., 1995), Russian (Matushansky, 2002) and Spanish (Bosque, 1999). I suspect that this is the norm rather than the exception. I would also guess that one doesn't find the reverse situation. Let us call a measure phrase when it combines with a plain adjective a 'direct measure phrase' (two feet tall) and we'll call a 
measure phrase when it combines with a comparative or too phrase an 'indirect measure phrase' (two feet taller). I hypothesize that:

(16) If a language has direct measure phrases, it will have indirect measure phrases, but not vice versa.

The universal in (16) says that direct measure phrases are marked. This markedness appears to influence acquisition (Snyder et. al., 1995). Our goal now is to say what the source of the markedness is.

\section{The Comparative: Measure phrases are predicates of gaps.}

If John is taller than Mary, then John's height exceeds Mary's. Taking tall to be a relation between individuals and their heights, we can express this fact with the formula in (17).

a. John is taller than Mary.

b. $\exists h_{j} \exists h_{m} \operatorname{tall}^{\prime}\left(j, h_{j}\right) \& \operatorname{tall}^{\prime}\left(m, h_{m}\right) \&\left(h_{j}>h_{m}\right)$

I am not spelling out the meanings for all the parts of the comparative construction. That would take us more deeply into the syntax of comparatives than we need to go. The formula in (17). is meant to show what the analysis should do. It crucially presupposes an ordering of points, in the case of tall we call them 'heights', and it presupposes that a gradable adjective denotes a relation between individuals and these ordered points (for further details see Cresswell, 1976).

If John's height indeed exceeds Mary's then there is a gap that spans from Mary's height up to John's. A measure phrase can be used to tell us what the size of that gap is. If John is 2 inches taller than Mary, then it's a two-inch gap. I express this fact with the formula in (18):

a. John is [2 inches] taller than Mary.

b. $\exists h_{j} \exists h_{m} \operatorname{tall}^{\prime}\left(j, h_{j}\right) \& \operatorname{tall}^{\prime}\left(m, h_{m}\right) \& 2-\operatorname{inches}\left(\left[h_{m} \rightarrow h_{j}\right]\right)$

$\left[h_{m} \rightarrow h_{j}\right]$ denotes the gap that spans from Mary's height, $h_{m}$, up to John's height, $h_{\mathrm{j}}$, and the measure phrase is treated as a predicate giving the size of that gap.

When we work with a ruler, we use the expression two inches in two different ways. On one use, two inches names the point labeled as such or the part of the ruler that extends from the left up to that point. On the other use, two inches is a predicate applying to any part of the ruler that is two inches long. It is this second predicative use that comes into play in the comparative. In the temporal domain these two uses are verbally distinguished. 5 o'clock on July 18, 1981 names a point on the time line and July 18, 1981 names a particular day-long interval. five hours, on the other hand, is a predicate, true 
of any interval of a certain size on the time line. Taking later than to express a relation between points on the time line, we use five hours to describe the gap introduced by the comparative (five hours later) and not 5 o'clock $(* 5$ o'clock later). This is the guiding intuition in formulating (18)..

If the purpose of a measure phrase is to describe a gap, and comparatives necessarily entail the presence of a gap, it is no surprise that they fit together so snugly. The same can be said for too. To say that John is too old to work is to say that there is a non-empty gap between John's age and the cutoff for working. And if the size of that gap is 20 years, then he is 20 years too old to work. Degree achievement verbs such as grandir 'grow' in (14). entail a gap between values taken at two different times, and the measure phrase indicates the size of the gap (Hay, Kennedy \& Levin, 1999). So-called degree heads do not always entail the presence of a gap. I may be as old as you, with no gap between our ages. And Frank may be old enough to work, with no gap between his age and the cutoff for working. Degree phrases headed by as or enough never have measure phrase specifiers ${ }^{8}$.

The idea that measure phrases are gap-predicates is not a new one. McConnell-Ginet (1973:135) introduces it in her account of comparatives. For some reason, the gap-predicate idea is absent from nearly every account of comparatives based on the premise that degrees are arguments of the compared predicate ${ }^{9}$. But as (18) shows, the gap-predicate idea is not incompatible with degrees as arguments and indeed I argue that it is the correct way of viewing measure phrases in these contexts.

Viewing measure phrases as gap-predicates allows us to understand how their internal semantics works. As noted above in connection with the comparative in (17), we assume a set of ordered points associated with a gradable predicate, in the case of tall we call these points heights. This set is presumably dense: for any two points, there is a third point that lies between them in the ordering. A predicate like foot is true of certain sets of these points. Which sets it is true of and which not is determined by a measure on the sets, the details of which it is the business of a theory of measurement to explicate. feet, the plural of the measure word foot, is true of any set of points $\mathrm{S}$ that can be partitioned into two or more subsets each of which is in the extension of foot. The quantifier that precedes the measure term tells us how many of these subsets are in the partition, in roughly the same way that it does in an ordinary plural such as 4 boys ${ }^{10}$. This analysis has an advantage over other accounts when one looks at a phrase like several feet tall. several feet is true of an interval of points if it can be partitioned into several subintervals each of which is a foot. Notice that there is no point on the scale corresponding to several feet, as would be required on the view that measure phrases denote points on the scale. And accounts that take measure nouns to denote two place relations between objects and numbers (Quine, 1960: 244- 
245; Krifka, 1989; Higginbotham, 1994; Chierchia, 1998:74) would be forced to analyze several as a number of sorts and would be hard pressed to explain the number marking on feet.

\section{The Positive}

We're taking gradable predicates to have degree arguments. This is reflected in our decision to present the analysis of the comparative in (17) in terms of a two place predicate tall' relating individuals to degrees. There are at least two ways to understand tall'( $\mathrm{x}, \mathrm{d})$ corresponding to the two glosses in (19), the latter following a suggestion in Kamp (1975):
a. $\operatorname{tall}^{\prime}(\mathrm{x}, \mathrm{d})$
"x's height is exactly d"
b. $\operatorname{tall}^{\prime}(\mathrm{x}, \mathrm{d})$
"x's height exceeds d"

Up to now I've been assuming the exactly-reading in (19a), however, the exceeds-reading is preferable if one wants to capture positive uses of tall, as in (20a) and (21a) below.
a. Jacob is tall and Kim is tall.
b. $\operatorname{tall}^{\prime}(\mathrm{j}, \mathrm{d})$ and tall'(k,d)
a. Jacob is tall but Esau is not tall.
b. tall'(j,d) and $\neg($ tall' $(e, d))$.

Assuming the exceeds-reading, we can capture the context dependence of the positive very simply by taking the context to supply a value for the free degree-argument (compare contextually supplied values for temporal, world or event arguments). When the context supplies a value for the degree argument, (20a) is true so long as both Jacob's and Kim's heights exceed this value. As Gawron (1995) points out, the exactly-reading would incorrectly predict (20a) to automatically be false if Jacob and Kim were not the same height.

Suppose now that Jacob and Kim were of different heights, but that the twins Jacob and Esau were equally tall. Whether or not (20) is true will depend on what value the context supplies and how precisely it supplies it. In some contexts, (20) will even be without a truth-value. But as Kamp (1975) and Kamp \& Partee (1995) discuss, (21) does not suffer the same fate. It will always be judged false because its truth does not vary with the particular choice of value for the degree argument. This difference between (20) and (21) is also captured on the exceeds-reading but not on the exactly-reading, along with a theory about how a parameter like the free degree variable in tall gets it value.

For these reasons we want to adopt the exceeds reading of tall' and this necessitates a modification in our analysis of the comparative, repeated below: 
(22) a. John is taller than Mary.

b. $\exists h_{j} \exists h_{m} \operatorname{tall}^{\prime}\left(j, h_{j}\right) \& \operatorname{tall}^{\prime}\left(m, h_{m}\right) \&\left(h_{j}>h_{m}\right)$

Given the exceeds reading recently adopted, for any $x$, tall'(x,d) is satisfied by many degrees : all those that lie below x's height. It is the upper limit for this set that is relevant to the comparative. So we need a formula as in (23).

$\exists \mathrm{h}_{\mathrm{j}} \exists \mathrm{h}_{\mathrm{m}}\left(\mathrm{h}_{\mathrm{j}}=\operatorname{UpLim}(\{\mathrm{d}: \operatorname{tall}(\mathrm{j}, \mathrm{d})\}) \wedge \mathrm{h}_{\mathrm{m}}=\operatorname{UpLim}(\{\mathrm{d}: \operatorname{tall}(\mathrm{m}, \mathrm{d})\}) \wedge\left(\mathrm{h}_{\mathrm{j}}>\mathrm{h}_{\mathrm{m}}\right)\right)$

The upper-limit also has a role to play in the semantics of de-adjectival nominalization. On the recently adopted view, tall is a predicate that relates $\mathrm{x}$ to any degree d relative to which $\mathrm{x}$ counts as tall. That leads to the following equation:

$$
\operatorname{height}(x)=\operatorname{UpLim}(\{\mathrm{d}: \operatorname{tall}(\mathrm{x}, \mathrm{d})\})
$$

Putting together (18), (23) and (24) we get:
a. John is [2 inches] taller than Mary.
b. 2-inches'([height'(m), height'(j)]).
c. the size of the interval from Mary's height to John's height is 2-inches.

\section{Adjectives modified by measure phrases are ambiguous}

In the introduction, I considered the illformedness of *John's height tall or *John's age old. I claimed that since degree arguments are 'functional' they cannot be saturated by a noun phrase, but can only be bound by functional heads such as the comparative. Another alternative is that the noun phrase could be an adjunct which functions semantically as a predicate of the degree argument. The formulas in (26)-(28b) illustrate this idea and how it parallels event-modifying adjuncts :

(26) a. Mary is [John's height] tall.

b. $\exists \mathrm{d}\left[\operatorname{tall}^{\prime}(\mathrm{m}, \mathrm{d}) \wedge\right.$ John's.height'(d)]

(27) a. John quickly left.

b. $\exists$ e [leaving'(e) $\wedge \operatorname{Agent}(\mathrm{e}, \mathrm{j}) \wedge$ quick'(e)]

a. Olga is a beautiful dancer.

b. [Gen e][dancing'(e, olga)] [beautiful'(e)]

(following Larson $1998^{11}$ )

While (26) conforms to the syntax-semantics constraints discussed in the introduction, it does not work semantically. John's height is a degreename, not a degree-predicate, as compared with quickly and beautiful both of which are event-predicates as required. What then happens when John's height is replaced with a measure phrase: 
(29) a. Mary is [5 feet $]$ tall.

b. $\exists \mathrm{d}\left[\operatorname{tall}^{\prime}(\mathrm{m}, \mathrm{d}) \wedge 5\right.$ feet $\left.^{\prime}(\mathrm{d})\right]$

(30) a. *Mary is [50 pounds] heavy.

b. $\exists \mathrm{d}\left[\operatorname{heavy}^{\prime}(\mathrm{m}, \mathrm{d}) \wedge 50\right.$-pounds'(d)]

Given what we said above, switching to a measure phrase should not improve matters. A measure phrase is a predicate of a set of degrees, in the case of the comparative this set is just the gap between the two degrees quantified over by the comparative (see (18)). In (29) and (30) the measure phrase is supplied a single degree not a gap. This makes the right prediction for (30), which is indeed ill formed. And it would make the right predictions for any language that doesn't allow direct measure phrases. But it fails for examples like (29) involving adjectives that do, exceptionally, allow direct measure phrase modification.

tall has to have a kind of meaning that allows for measure phrase modification. It must undergo a lexical rule that produces homonyms and these homonyms have to have interval arguments (sets of degrees) in place of degree arguments. Such a rule is given in (31):

(31) Homonym Rule: from degrees to intervals.

If $\mathrm{A}$ has meaning $\mathrm{A}^{\prime}$ that relates individuals to degrees then $\mathrm{A}$ has a secondary meaning relating individuals to sets of degrees (intervals).

The secondary meaning is given by $: \lambda \mathrm{I} . \lambda \mathrm{x} . \mathrm{I}=\left\{\mathrm{d}: \mathrm{A}^{\prime}(\mathrm{x}, \mathrm{d})\right\}$

Homonym Rule applies to tall, wide, deep, thick, old, long, high.

Following the translation scheme used so far, we'll translate tall on its primary meaning as tall ' and on its secondary meaning we'll translate it as tall ${ }_{2}$. According to the rule in (31), tall ${ }_{2}$ relates an individual $x$ to an interval and that interval is just the set of all points on the scale that tall ${ }_{1}$ relates $\mathrm{x}$ to. The rule in effect collects together all the degrees related to an individual in a way reminiscent of how, on some accounts, the definite article collects all the individuals in the extension of boy to give the meaning of the boys. The rule is effectively a type-shifting rule targeting the degree argument ${ }^{12}$.

(29) now needs to be revised as follows :
a. Mary is [5 feet] tall.
b. $\exists \mathrm{I}\left[\operatorname{tall}_{2}^{\prime}(\mathrm{m}, \mathrm{I}) \wedge 5\right.$ feet'(I)]

Given the rule in (31), (33b), is equivalent to:

5 feet' $\left(\left\{\mathrm{d}: \operatorname{tall}_{1}{ }^{\prime}(\mathrm{x}, \mathrm{d})\right\}\right)$

Putting this together with what was said above about the comparative in (25) we have the following entailment. If Chris is 5 feet taller than his infant son, and Mary is 5 feet tall, then the interval that includes all the points on the scale 
below Mary's height is the same size as the interval stretching from Chris' infant son's height up to his own. Furthermore, each of these intervals can, given what we said about the semantics of measure phrases, be partitioned into five intervals each of which counts as a foot ${ }^{13}$.

\section{Antonyms}

In order to see what goes wrong in $* 5$ feet short, we need to think a bit about the structure of the relevant scale as it compares with the scale for tall.

Consider first the sets in (35) and (36) of the kind produced by the Homonym Rule :

$$
\{\mathrm{d} \text { : John's height exceeds } \mathrm{d}\}
$$

$$
\{\mathrm{d} \text { : The height of the Eiffel Tower exceeds d\} }
$$

Both of these sets have an upper bound, given by the respective heights of the Eiffel Tower and of John. These sets share a lower bound. It's the lower bound for the scale itself; the height that things approach as they become less and less tall. Consider now the scale that includes the degrees for the predicate short. The points themselves are the same as those for the scale for tall. The same measure terms apply to sets of them. 3 inches shorter appears alongside 3 inches taller. The difference comes in the ordering of the points. If the Eiffel Tower's height is greater than John's relative to the tall-ordering, then the Eiffel Tower is taller than John. In that case, John's height is greater than the Eiffel Tower's height relative to the short-ordering, and so John is shorter than the Eiffel Tower. Let us now imagine that the Homonym Rule applied to short. In that case, it would produce sets like in (37), where I've subscripted "exceeds" to indicate that it is higher relative to the short-ordering:

$$
\left\{\mathrm{d} \text { : John's height exceeds } \text { short }_{\mathrm{d}} \mathrm{d}\right. \text { \} }
$$

Like with (35), John's height is the upper bound for this set, but unlike (35),

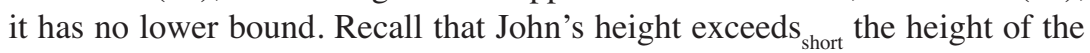
Eiffel Tower hence the height of the Eiffel Tower is in (37). Likewise for the heights of even taller structures, ad infinitum. (37) has an upper bound but no lower bound.

Since the set in (37) has no lower bound, it couldn't be partitioned into a finite number of subsets each of which counts as a centimeter or a meter or even a kilometer. For any finite $\mathrm{n}$ then, $n$ meters short would be false. For this reason it is not surprising that the Homonym Rule has not caught short in its net. Similar reasoning applies to all the antonyms of the adjectives to which the rule in fact applies $[\text { see (5) }]^{14}$. 
The two pictures below serve to illustrate the ideas in this and the preceding three sections. Looking first at the picture on the left, imagine that I've taken a set of bars of varying lengths and ordered them one above the other, in increasing length. I draw a line next to the boards and on it I put numbers corresponding to the boards. These numbers and the ones that come between them represent our degrees. If the contextually specified degreevalue is 1 then A and B count as long. If 3 is the contextually specified degree, then $\mathrm{A}$ is long but $\mathrm{B}$ is not. All of the points below 4 are those relative to which A counts as long. The upper limit for that set is 4 which we now identify with the length of A. In similar fashion we identify 2 as the length of B. A is longer than B because 4 is higher than 2 . Now, we introduce a measure term, call it meter. We say that meter is true of the set of points between 0 and 1 , between 1 and 2, and so on. The set of points between 2 and 4 can be partitioned into two meter-intervals, hence the truth of $A$ is two meters longer than $B$. Since the interval between 0 and 4 is partitionable into 4 meter-intervals, $A$ is 4 meters long is true.

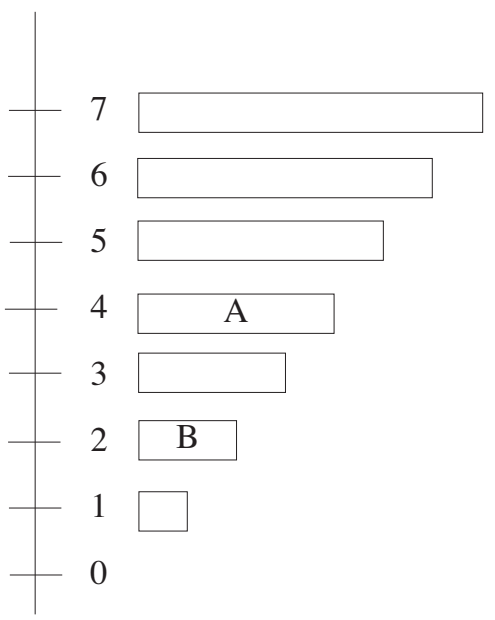

long scale

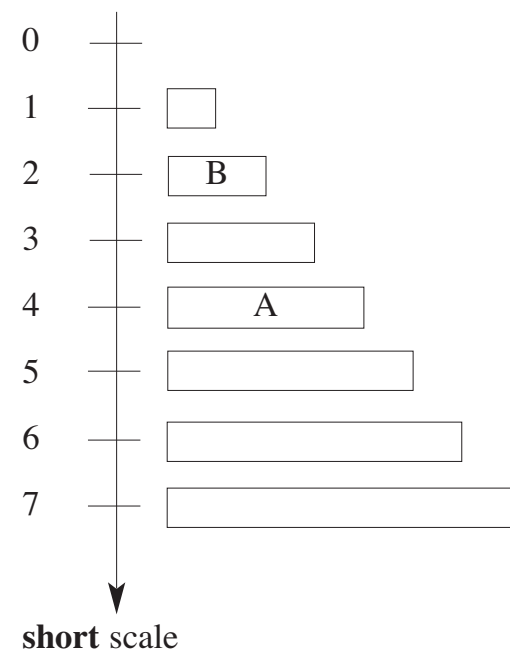

Now we turn to the picture on the right. Once again I've piled my bars one on top of the other, but this time I've piled them in increasing order of shortness. I draw a line next to the boards and put numbers corresponding to the boards. These numbers and those numbers that come between them represent our degrees. If the contextually specified degree-value is 5 then $\mathrm{A}$ and B count as short. If 3 is the contextually specified degree, then B is short but A is not. All of the points below 4 are those relative to which A counts as short. The upper limit for that set is 4 which we now identify with the shortness of A. In similar fashion we identify 2 as the shortness of B. B is shorter than A because 2 is higher than 4 . Now, we introduce a measure term, 
call it meter. We say that meter is true of the set of points between 0 and 1 , between 1 and 2, and so on. The set of points between 2 and 4 can be partitioned into two meter-intervals, hence the truth of $B$ is two meters shorter than $B$. The set of degrees relative to which $\mathrm{A}$ is short, in other words those that satisfy short'(a,d), have 4 as the upper bound but no lower bound. For finite $n, n$ meters could never be true of that interval and hence it is no surprise that the Homonym Rule does not apply to short.

\section{The Homonym Rule and others like it}

The adjective strong, the antonym of weak, at first appears not to be one of those adjectives to which the homonym rule applies. A wind may be described as 10-25 mph stronger than another, but never as *10 mph strong. But there is another use of strong that appears exclusively with measure phrases and has to do with numerical size. Focusing on that use we have the following pattern of data:

The army is $*(1000$ men) strong.

*This army is stronger than that one.

(40) *How strong is their army?

This behavior can be explained by assuming that the second use of strong while not the product of the homonym rule, does have a meaning of that type, relating individuals to intervals. Since contexts supply degrees and not intervals, it cannot be used in the positive. Degree quantifiers bind variables over points on the scale and so they cannot bind the degree argument of strong on this use. German schwer may be another example of this type. It normally means 'heavy', but in conjunction with the right kind of measure phrase it can mean 'rich', however it can't be used in a comparative with this meaning:

$$
\begin{aligned}
& 46000 \text { Euro schwer. } \\
& 46,000 \text { Euro rich } \\
& \text { 'worth 46,000 Euro' }
\end{aligned}
$$

In section 2, I observed that for the most part, the adjectives in English that fall under the homonym rule are a subset of those that do in German. spät 'late' and früh 'early' are exceptions to this rule. They take direct measure phrases in English but not in German. But on closer inspection, latelearly pattern more like covert comparatives and may not fall under the homonym rule even in English. late and early can take their measure phrase in the form of a following by phrase, like comparatives and not like other absolute adjectives : 
(43) He was late, by just two minutes.

(44) *He was tall, by just four feet.

(45) He was taller than me, by just four inches.

In fact, the semantics of 5 minutes late could not be the result of an 'application' of the homonym rule. Judging from its use in comparatives such as The American revolution was later than the French revolution, late relates events to times, with the times ordered in the direction of the flow of time (early uses the opposite ordering). If we assume that time extends backwards indefinitely then late is like short having no lower bound on the scale it makes use of. And even if we assume there is a first moment, 5 minutes certainly is not measuring a set of times whose lower bound is the first moment. Thus we must assume that alongside our homonym rule in (31), there are other lexical rules that apply to adjectives to produce covert comparatives. A related rule applies in some languages to certain adjectives to produce comparative meanings ${ }^{15}$. These adjectives can dispense with the comparative morpheme. This is illustrated with big versus sick in the following Modern Hebrew examples :

(yoter) gadol mimeni.
more big than-me
'bigger than me'

(yoter) gadol mimeni. 'bigger than me' *(yoter) xole mimeni. more sick than-me 'sicker than me'

The adjective short in five dollars short may be an adjective whose single meaning is of the kind that is produced by the late/early rule. It takes a by phrase, it won't go into the comparative and it is interpreted relative to some reference point.

The key idea here is that as a rule gradable adjectives do not have the right kind of meaning to be directly modified by a measure phrase. In certain exceptional cases, those that fall under the Homonym Rule (31), the adjective's meaning allows for this combination. Murphy (1997), following Lehrer (1985) and Givón (1970), takes the opposite view. For her, the adjective occurs inside the measure phrase. And the question of whether a measure phrase will take an adjective or not depends on the measure term itself. She writes "adjectives occur in measure phrases just in those cases where ambiguity is a problem (because the same unit of measurement can occur in different dimensions or with different starting points)". I am sympathetic with this idea as part of an account of which adjectives are likely to acquire homonyms of the kind described by the Homonym Rule. I do not however see that this account could replace the one proposed here. Measure terms for weight are presumably no less ambiguous in German or Italian than they are in French or English, nevertheless these languages differ with respect to whether heavy and its cognates combine with a measure phrase. Pressure 
to eliminate ambiguity could push one way or the other, but it can't predict whether a particular measure phrase goes with a particular adjective or not. The pragmatic view focuses on the meaning of the measure term while the Homonym Rule focuses on the adjective. The Homonym Rule is needed to explain the contrast between 2 inches high and $* 2$ inches close to the desk which involve the same ambiguous measure phrase but different adjectives. Nonce measure phrases provide an extreme case of this type. One can say 2 cars deep and 2 cars wide but not *2 cars heavy. In the first two cases, the adjective combines with a measure phrase and one is able to interpret car as a unit of depth or width, as needed. The problem with $* 2$ cars heavy is that heavy doesn't allow measure phrase modification, and not that we have a problem understanding car as a unit of weight.

The Homonym Rule is one source of measure phrase modifiable adjectives. Another source is a rule that creates covert comparatives. And still other adjectives are unambiguous interval-predicates. These do not participate in those constructions that rely on having a degree argument.

\section{Noun Phrase Adjuncts}

*Jack's height tall is ungrammatical because even though Jack's height names a degree and tall has a degree argument, it is not the sort of argument that can be saturated by anything but a functional head. What is permitted, however, is for a non-functional phrase to act as a modifier, predicating upon the degree argument of an adjective. Jack's height couldn't do that because it isn't a predicate of degrees. Measure phrases can't in general perform this task either because their semantics is that of a predicate of sets of points on a scale, while the degree argument of tall is interpreted as a point on the scale. The homonym rule applies to tall and some other adjectives to effectively typeshift their degree argument from a point interpretation to a set-of-points-, or interval-, interpretation paving the way for measure phrase modifiers.

From a formal point of view, measure phrases are completely ordinary noun phrases. They show a number distinction of a familiar kind ( 1 foot, 2 feet, several feet) and their heads combine with specifiers and even some modifiers (several dusty feet long - see Klooster, 1972) in a way that is typical of nouns. This raises the question of their status as adjuncts. How are they assigned case, for example? Why don't they need to appear inside a prepositional phrase or with adverbial morphology? I don't have anything substantial to add on this topic, I merely want to point out that they form part of larger class of adjunct noun phrases.

Given the parallels I've drawn between degree arguments and temporal arguments, it is natural to want to analogize measure phrases in AP to bare-NP adverbs [Saturday in (48)]. Whatever the correct story is on these 
(Larson, 1985; McCawley 1988), they behave quite differently from measure phrases. In the case of bare-NP adverbs, it is a special fact about the noun phrase itself that allows it to occur as an adjunct, as the contrast in (48) shows:
a. She left Saturday.
b. *She left the weekend.

Measure phrases are not so constrained. An adjective, if it takes a direct measure phrase, will take any relevant one ${ }^{16}$, even nonce ones: the pile was five prisoners high.

Another place to look for counterparts of measure phrase modifiers is among event adverbials. I think a good analogy does hold between measure phrases and what Pereltsvaig $(1999,2001)$ has dubbed "adverbial cognate objects". The verbs in Pereltsvaig's examples (49) and (50) have cognate objects, so-called because the noun is morphologically related to the governing verb.

(49) Paul danced a (slow) dance.

(50) Il a dansé une grande danse.

(French)

he has danced a grand dance

'He danced a grand dance.'

According to Pereltsvaig and others (see references in Pereltsvaig, 2001), these cognate objects are actual arguments of the verb. By contrast, there are cognate objects in Hebrew, Russian, Èdó, and Vietnamese that are not arguments. These are the adverbial cognate objects, an example of which appears in (51) below:

$$
\begin{aligned}
& \text { hezin.u 'oto hazana melaxutit. } \\
& \text { they-fed him feeding artificial } \\
& \text { 'They fed him artificially.' }
\end{aligned}
$$

(Modern Hebrew)

(Mittwoch, 1998: 314)

The verb in (51) has a true object in addition to the cognate object, a sign that the cognate-object is adverbial. Adverbial cognate objects can appear with a much wider variety of verbal predicates than can true objects. Adverbial cognate objects may even modify adjectival predicates:

$$
\begin{aligned}
& \text { hu 'axrai 'axra'yut 'elyona } \\
& \text { he responsible responsibility supreme } \\
& \text { 'He has supreme responsibility.' }
\end{aligned}
$$

(Modern Hebrew)

(Mittwoch, 1998: 314)

The 'cognate' requirement may be traced to the fact that the noun is interpreted as a predicate of events of the kind given by the verb. A noncognate noun would pick out different kinds of events. In other words, it is not exactly a property of the noun itself that allows it to be a cognate object, rather 
it is the fact that the noun and the verb predicate of the same kinds of events. In similar fashion, measure phrases and adjectives like tall $_{2}$ or long $_{2}$ fit together because they are predicates of the same kinds of objects - intervals of a given sort.

Adverbial cognate objects have a number of distinctive properties that follow from their role as predicates. They can't be formed with strong quantifiers and they can't be referential definites or pronominal ( $c f$. Moltmann, 1989; Mittwoch, 1998; Pereltsvaig, 1999, 2001). Direct measure phrases obey these same constraints :

*every inch tall.

*most years old.

(54) *my height tall.

(55) He knows [your height $]_{i}$ and he told me it.

*It turns out I'm also it, tall.

(56) He knows [your age $]_{\mathrm{i}}$ and he told me it.

*It turns out I'm also $i_{i}$ old.

Since measure phrases always have predicative semantics, these constraints are obeyed wherever measure phrases are used (Klooster, 1972: 18ff; Jackendoff, 1977: 163):
a. *He's most feet taller.
b. *most feet of yarn
c. *He ran most miles.
d. *Most inches above the painting.
e. *It weighs almost every ton.

Mittwoch (1998) reports an observation of Edit Doron's to the effect that a cognate object does not interact scopally with an argument NP with which it shares a clause. For example, (58) doesn't allow a reading in which the six visits are spread over different patients :

(58) ha-rofe biker xole yapani šiša bikurim.

(Modern Hebrew)

the-doctor visited patient Japanese six visits

'The doctor paid six visits to a Japanese patient.' (Mittwoch, 1998: 324)

Again, this follows from the predicative semantics of the adverbial cognate object. It is not a quantifier over visits but rather a predicate of events. Direct measure phrases likewise don't interact scopally with argument NPs with which they share a clause. (59) below is not scopally ambiguous ${ }^{17}$.

(59) Every pig is exactly two days old. 


\section{Conclusion}

There are two possible kinds of non-thematic argument that a gradable adjective could have. The first possibility is that the non-thematic argument is a degree argument. This argument can be bound by degree operators such as the comparative, too and enough. These operators can bind non-thematic arguments, because they are functional morphemes. The other possibility is that the non-thematic argument is a sets-of-degrees or interval argument. Measure phrases are predicates of intervals hence they can be used as predicates of these arguments. This is what happens in the phrase 2 inches thick. Measure phrases have the syntax of noun phrases and, it turns out, their interpretation follows familiar noun phrase semantics. Measure phrases do not have functional heads but this does not prevent them from predicating of non-thematic arguments. They follow the same pattern as adverbial cognate objects which are noun phrase predicates of event arguments.

\section{NOTES}

1. This paper benefited greatly from colloquium audiences at U. Connecticut, U. Delaware, U. Maryland and UCLA, from seminar participants at Rutgers U. and Humboldt U. (Berlin), from conversations with Renate Raffelsiefen and Jane Grimshaw and from comments of two anonymous reviewers. Daniel Büring and Ora Matushansky posed questions that really shook the foundations and caused me to completely rethink the analysis.

2. This idea is found, for example, in Cresswell (1976), von Stechow (1984), Heim (2001), Matushansky (2002: section 1.1.1), Meier (2003: section 2.3).

3. A 'pre-adjectival measure phrase' sits right next to the adjective, to the left in English, to the right in other languages. I use this term to exclude examples where the adjective is in the comparative form or where a too intervenes: five feet taller, five feet too tall.

4. Thanks to Renate Raffelsiefen for this point. The predicate-argument generalization goes back at least to Schmerling (1976). It has been understood in terms of 'integration' by Jacobs (1991), and in terms of 'focus-domains' by Gussenhoven (1984,1992).

5. From Gawron (1995).

6. For the French data I thank Viviane Déprez, Philippe Schlenker and an anonymous reviewer. For the German data, I thank Cécile Meier, Renate Raffelsiefen and Alex Zepter.

7. gross takes measure phrases for 1 and 2 dimensional uses, but not for 3 dimensional uses.

8. Superlatives like hottest present an interesting case. They appear to presuppose a gap between the highest ranked entity and those below it. It would be odd to declare my coffee to be the hottest if we all have equally hot coffee. Measure phrases are not allowed to the left of the adjective: $* 2^{\circ}$ hottest, but they do appear in a following by phrase: the hottest, by $2^{\circ}$. For illuminating discussion of this case see Stateva (2003). 
9. Faller (1999) and Winter (2001) are recent exceptions to this generalization. 10. And as an editor pointed out, when the number of subsets is given by a real number other than one, we use the plural: 2,5 feet, zero feet, just as with concrete nouns : 2,5 oranges, zero oranges.

11. (28) is a specific case of a general phenomenon discussed in Bouchard (1998) whereby a pre- $\mathrm{N}$ adjective modifies a component internal to $\mathrm{N}$.

12. This follows up on Fillmore (1965)'s idea that tall gets assigned a second sense that shows up in the presence of measure phrases but short does not.

13. I've assumed that the measure function on which the meaning of foot is based does not discriminate between the open interval $(a, b)$ and the closed interval $[a, b]$. I believe this is standard. These intervals differ by single points, which are of measure 0 .

14. This account agrees with Hale (1970), Bierwisch $(1967,1989)$, Seuren (1978) and Faller (1999) in tracing the infelicity of $* 5$ meters short to the fact that the scale associated with short has no lower bound or zero-point. Winter (2001) takes the opposite view. He attributes the oddity of *five feet short to the fact that there is a maximum short-degree rather than to the fact that there is no minimum short-degree. Cresswell (1976), von Stechow (1984) and Kennedy (2001) distinguish tall-degrees from short-degrees and they say that 5 meters denotes a tall-degree.

15. Thanks to Ora Matushansky for pointing out this connection.

16. much, a lot and a little share much of the distribution of measure phrases. They all, for example, appear with the comparative: much taller. much and a lot do not combine directly with adjectives, although a little does to some extent. I assume an 'elsewhere' account for *much tall along the lines of Doetjes (2001).

17. In (59), old is a predicate of intervals and so is the measure phrase. For the measure phrase to take scope over the subject quantifier it would have to be a quantifier itself, a quantifier over degrees, and old would have to be a predicate of degrees. If that were possible, then the wide scope reading would be given by:

(i) [exactly two days $]_{1}$ every pig was $t_{1}$ old.

The underlined scope of the measure phrase quantifier would be true of a degree just in case every pig were old relative to that degree. In other words, it would be true of all degrees that lie below the age of the youngest pig. (59), if it had such a reading, could mean that the youngest pig was more than 2 days old.

\section{BIBLIOGRAPHY}

Bierwisch, M. (1967). Some Semantic Universals of German Adjectivals. Foundations of Language 3: 1-36.

Bierwisch, M. (1989). The Semantics of Gradation. In M. Bierwisch \& E. Lang (eds.), Dimensional Adjectives: Grammatical Structure and Conceptual Interpretation: 71-261. Berlin: Springer-Verlag.

BosQue, I. (1999). El sintagma adjetival. Modificadores y complementos del adjetivo. Adjetivo y participio. In I. Bosque \& V. Demonte (eds.), Gramática Descriptiva de la Lengua Española, Vol. 1. Chapter 4: 217-310. Madrid: Espasa Calpe. 
Bouchard, D. (1998). The Distribution and Interpretation of Adjectives in French: A Consequence of Bare Phrase Structure. Probus 10 : 139-183.

Chierchia, G. (1998). Plurality of Mass Nouns and the Notion of Semantic Parameter. In S. Rothstein (ed.), Events and Grammar: 53-103. Dordrecht: Kluwer.

Corver, N. (1990). The Syntax of Left Branch Constructions, Ph.D dissertation, Tilburg University.

Cresswell, M. J. (1976). The Semantics of Degree. In B. Partee (ed.), Montague Grammar: 261-292. New York: Academic Press.

Doetjes, J. (2001) . Beaucoup est ailleurs. Expressions de degré et sous-spécification catégorielle. In R. Bok-Bennema, B. de Jonge, B. Kampers-Manhe \& A. Molendijk (eds.), Adverbial Modification: 125-138. Amsterdam: Rodopi.

FAller, M. (1999). Dimensional Adjectives and Measure Phrases in Vector Space Semantics. In M. Faller, S. Kaufmann, \& M. Pauly (eds.), Formalizing the Dynamics of Information Stanford: CSLI Publications.

FILlmore, C.J. (1965). Entailment Rules in a Semantic Theory. POLA Report 11, Ohio State University. Published in J. F. Rosenberg \& C. Travis (eds.), Readings in the Philosophy of Language: 533-47. Englewood Cliffs, N.J.: Prentice Hall, Inc. 1971.

Gawron, J-M. (1995). Comparatives, Superlatives, and Resolution. Linguistics and Philosophy 18 : 333-380.

Givón, T. (1970). Notes on the Semantic Structure of English Adjectives. Language 46: 816-837.

Gussenhoven, C. (1984). On the Grammar and Semantics of Sentence Accents. Dordrecht: Foris.

Gussenhoven, C. (1992). Sentence Accents and Argument Structure. In I.M. Roca (ed.), Thematic Structure: Its Role in Grammar. New York: Foris.

Hale, A. (1970). Conditions on English Comparative Clause Pairings. In R. Jacobs \& P. Rosenbaum (eds.), Readings in English Transformational Grammar. Washington: Georgetown University Press.

Hay, J., C. Kennedy, \& B. LeVIn (1999). Scalar Structure Underlies Telicity in Degree Achievements. In T. Matthews \& D. Strolovitch (eds.), Proceedings of SALT 9. Ithaca, NY : Cornell University.

Heim, I. (2001). Degree Operators and Scope. In C. Féry \& W. Sternefeld (eds.), Audiatur Vox Sapientiae: A Festschrift for Arnim von Stechow: 214-239. Berlin: Akademie Verlag.

Higginbotham, J. (1994). Mass and Count Quantifiers. Linguistics \& Philosophy 17: 447-80.

Higginbotham, J. (1985). On Semantics. Linguistic Inquiry 16: 547-593.

JACKENDOFF, R. (1977). X-Bar Syntax : A Study of Phrase Structure. Cambridge, MA : MIT Press.

JACOBS, J. (1991). Focus Ambiguities. Journal of Semantics 8: 1-36.

KAMP, H. \& B. PARTEE (1995). Prototype theory and compositionality. Cognition 57 : 129-191.

Kamp, J. A. W. (1975). Two Theories about Adjectives. In E. L. Keenan (ed.), Formal Semantics of Natural Language: 123-155. Cambridge : Cambridge University Press. 
Kennedy, C. (1999). Projecting the Adjective: The Syntax and Semantics of Gradability and Comparison. New York: Garland.

Kennedy, C. (2001). Polar Opposition and the Ontology of 'Degrees'. Linguistics and Philosophy 24 : 33-70.

KleIN, H. (1998). Adverbs of Degree in Dutch and Related Languages. Amsterdam: John Benjamins.

Klooster, W. G. (1972). The Structure Underlying Measure Phrase Sentences. Dordrecht: Reidel.

KRIFKA, M. (1989). Nominal Reference, Temporal Constitution and Quantification in Event Semantics. In R. Bartsch, J. van Benthem \& P. van Emde Boas (eds.), Semantics and Contextual Expressions: 75-115. Dordrecht: Foris.

LARSON, R.K. (1985). Bare-NP Adverbs. Linguistic Inquiry, 16: 595-621.

LARSON, R.K. (1998). Events and Modification in Nominals. In D. Strolovitch \& A. Lawson (eds.), Proceedings from Semantics and Linguistic Theory (SALT) VIII : 145-168. Ithaca, NY : Cornell University.

LEHRER, A. (1985). Markedness and Antonymy. Journal of Linguistics 21 : 397-429.

Matushansky, O. (2002). Tipping the Scales: The Syntax of Scalarity in the Complement of Seem. Syntax 5.3: 219-276.

McCAWLeY, J.D. (1988). Adverbial NPs: Bare or Clad in See-Through Garb? Language 64 : 583-590.

McConnell-Ginet, S. (1973). Comparative Constructions in English: A Syntactic and Semantic Analysis. PhD dissertation, University of Rochester.

MeIER, C. (2003). The Meaning of too, enough and so...that. Natural Language Semantics $11: 69-107$.

Mitтwoch, A. (1998). Cognate Objects as Reflections of Davidsonian Event Arguments. In S. Rothstein (ed.), Events and Grammar: 309-332. Dordrecht: Kluwer.

Moltmann, F. (1989). Nominal and Clausal Event Predicates. In C. R. Wiltshire, R. Graczyk \& B. Music (eds.), Papers from the 25th Annual Regional Meeting of the Chicago Linguistic Society: 300-314. Chicago, IL: University of Chicago.

Murphy, M. L. (1997). Why Adjectives Occur (Or Don't) in Measure Phrases. Annual Meeting of the Linguistic Society of America. Chicago, 2-5 January.

Pereltsvaig, A. (1999). Two Classes of Cognate Objects. In K. Shahin, S. Blake, \& E.-S. Kim (eds.), The Proceedings of the WCCFL XVII : 537- 551. Stanford, CA : CSLI.

Pereltsvaig, A. (2001). Cognate Objects in Modern and Biblical Hebrew. In J. Ouhalla \& U. Shlonsky (eds.), Themes and Issues in Arabic and Hebrew: 133. Dordrecht: Kluwer.

Postal, P. (1974). On Certain Ambiguities. Linguistic Inquiry 5 : 367 - 424.

Quine, W.V.O. (1960). Word and Object. Cambridge, MA: MIT Press.

Schmerling, S. F. (1976). Aspects of English Sentence Stress. Austin: University of Texas.

SEuren, P. A. M. (1973). The Comparative. In F. Kiefer \& N. Ruwet (eds.), Generative Grammar in Europe. Dordrecht: Reidel.

Seuren, P. A. M. (1978). The Structure and Selection of Positive and Negative Gradable Adjectives. In D. Farkas, W. M. Jacobson \& K. Todrys (eds.), Papers 
from the 25th Annual Regional Meeting of the Chicago Linguistic Society. Parasession on the Lexicon: 336-346. Chicago, IL: University of Chicago.

SNyder, W., K. WeXler, \& D. DAs (1995). The syntactic representation of degree and quantity: Perspectives from Japanese and child English. In R. Aranovich et al. (eds.), Proceedings of the West Coast Conference on Formal Linguistics XIII. Stanford, CA : CSLI.

Stateva, P. (2000). In Defense of the Movement Theory of Superlatives. In R. Daly \& A. Riehl (eds.), Proceeding of ESCOL 1999: 219-226. (Distributed by Cornell Linguistics Club).

Stateva, P. (2003). Superlative more. In Robert B. Young \& Yuping Zhou (eds.), Proceedings of SALT 13: 276-291. Ithaca, NY : Cornell University.

vON Stechow, A. (1984). My Reaction to Cresswell's, Hellan's, Hoeksema's, and Seuren's Comments. Journal of Semantics 3: 183-199.

Winter, Y. (2001). Measure Phrase Modification in Vector Space Semantics. In K. Megerdoomian \& L.A. Bar-el (eds.), WCCFL 20 Proceedings: 607-620. Somerville, MA: Cascadilla Press.

Zamparell, R. (2000). Layers in the Determiner Phrase. New York: Garland.

\section{RÉSUMÉ}

Dans certaines langues, les syntagmes de mesure peuvent apparaître avec des adjectifs non comparés (165 cm tall 'haut de $165 \mathrm{~cm}$ '). Je traiterai trois questions concernant cette construction : (a) le syntagme de mesure est-il un argument de l'adjectif ou plutôt un adjoint ? (b) quel statut doit-on donner au fait que cette construction est lexicalement restreinte à certains adjectifs $(* 5 \mathrm{~kg}$ heavy 'lourd de $5 \mathrm{~kg}$ ')? (c) pourquoi cette restriction lexicale disparaît-elle une fois que l'adjectif apparaît au comparatif (5 kg heavier 'plus lourd de $5 \mathrm{~kg}$ ')? Je propose que le syntagme de mesure est un adjoint qui modifie l'argument de degré des adjectifs, comparable aux adverbes modifiant l'argument d'événement du SV. L'argument de degré lui-même ne peut être saturé que par un élément fonctionnel. Le type sémantique des syntagmes de mesure n'est compatible avec une prédication directe d'un argument de degré que dans les comparatifs. Par conséquent, je propose un changement de type semblable à celui qui se produit dans les comparatifs. Cette règle est ici lexicalement conditionnée s'appliquant à tall mais non à heavy.

\section{MoTS CLÉS}

Adjectif, syntagme de mesure, degré, catégorie fonctionnelle, lexical, adjoint, argument, antonymie. 